\title{
Arsenic in your food: potential health hazards from arsenic found in rice
}

\author{
This article was published in the following Dove Press journal: \\ Nutrition and Dietary Supplements \\ 9 January 2015 \\ Number of times this article has been viewed
}

\author{
Sandra Munera-Picazo' \\ Marina Cano-Lamadrid' \\ María Concepción Castaño- \\ Iglesias ${ }^{2}$ \\ Francisco Burló' \\ Ángel A Carbonell- \\ Barrachina' \\ 'Food Quality and Safety Group, \\ Department of Agro-Food Technology, \\ Universidad Miguel Hernández, \\ Orihuela, ${ }^{2}$ Servicio de Pediatría, \\ Hospital Universitario San Juan de \\ Alicante, Alicante, Spain
}

\begin{abstract}
Rice is a staple food for over half of the world population, but there is some concern about the occurrence of arsenic (As) in this cereal and the possible overexposure to this metalloid. Recently, the Codex Alimentarius Commission established a maximum limit of $200 \mu \mathrm{g} \mathrm{kg}^{-1}$ for inorganic arsenic (iAs) in rice. Because the maximum content of As in water has been reduced to $10 \mu \mathrm{g} \mathrm{L}^{-1}$, intoxication through rice and rice-based products can be considered an important source of As poisoning. The chronic effects of this iAs exposure can be lung and bladder cancer, skin lesions, or other noncarcinogenic diseases. There is clear evidence of high levels of iAs in rice and rice-based products. Different solutions for the reduction of As intake are proposed at different levels: 1) during the plant-growing process through agronomic practices, 2) pretreatment of rice before its use in the food industry, 3) optimization of the conditions of unit operations during processing, and 4) by cooking.
\end{abstract}

Keywords: arsenic speciation, food safety, dietary exposure, Oryza sativa

\section{Introduction}

It is very well known that rice (Oryza sativa) is a staple food for over half of the world population. It is also the second cereal crop after maize, with an estimated production in 2013 of 745 million tons (497 million tons of rice milled for human consumption). ${ }^{1}$

The main reason for the well-established relationship between rice and arsenic (As) is the peculiar growing conditions (flooded soils) of rice. In the past, many fertilizers containing organic As (oAs) were used as pesticides or defoliants. Now, although its use is prohibited or has been minimized, the presence of As in soils and groundwater persists to this day. Therefore, flooded soils offer a unique environment for growth and nutrition of rice, but at the same time, they are the perfect scenarios for the highest possible availability of As for rice plants. ${ }^{2}$

There are four elements, iron (Fe), phosphorus (P), sulfur (S), and silicon ( $\mathrm{Si}$ ), that interact strongly with As during its route from the soil to the plants. Plants take up arsenate $[\mathrm{As}(\mathrm{V})]$ through the phosphate transporters, and arsenite $[\mathrm{As}(\mathrm{III})]$ and undissociated methylated As species through the nodulin 26-like intrinsic aquaporin channels. Arsenate is readily reduced to arsenite in the plant, which is later detoxified by complexation with thiol-rich peptides such as phytochelatins and/or vacuolar sequestration. ${ }^{3}$

While the maximum limit of As in water is highly regulated worldwide (10 $\mathrm{mg} \mathrm{L}^{-1}$ ), the maximum level of As residues in highly consumed foods, such as rice, is still a pending matter; the main reason is political because none of the governmental organizations want to set up a maximum threshold for iAs, which can 
jeopardize their rice production. Although there is serious concern about the presence of As in this cereal and the possible overexposure, no international agency dealing with food safety, such as the European Food Safety Authority (EFSA), the Food and Drug Administration of the United States, and the Food and Agriculture Organization of the United Nations (FAO), have yet established maximum limits for this pollutant in rice or rice-based products; however, all of them are intensively working on this topic, as of 2014. People's Republic of China is the country with the strictest regulation, with a maximum threshold of $150 \mu \mathrm{g}$ iAs $\mathrm{kg}^{-1}$. Very recently, toward the end of July 2014, the Codex Alimentarius Commission has established a maximum limit of $200 \mu \mathrm{g}$ iAs $\mathrm{kg}^{-1}$, which is more permissible than that of People's Republic of China. In addition, all previously cited organizations are compiling global data on total As (tAs) and iAs in polished rice and rice-based products, in order to establish an appropriate maximum residue level that reflects the actual content of this metalloid and that does not jeopardize the international rice market. ${ }^{4}$ If an exceedingly low maximum residue limit is established for iAs in rice, a global crisis can be created and the safe supply of rice worldwide could be threatened; this situation could generate a significant international crisis, especially affecting the poor segments of countries that highly depend on rice as the staple food.

As for the maximum safe intake of this toxic substance, in 1988, The Joint FAO/WHO (World Health Organization) Expert Committee on Food Additives proposed a provisional tolerable weekly intake of $15 \mathrm{mg} \mathrm{kg}^{-1}$ body weight (bw). But in 2011, this value was discarded because the EFSA concluded in 2009 that a single value was not appropriate because intakes between $0.3 \mu \mathrm{g} \mathrm{kg}^{-1}$ bw and $8.0 \mu \mathrm{g} \mathrm{kg}$ bw are within the benchmark dose lower confidence limit $\left(\mathrm{BMDL}_{01}\right)$ for certain types of cancer. At the moment, there is no maximum safe intake value set up by any international food safety authority. ${ }^{5,6}$

\section{Potential health hazards and risks resulting from dietary As}

Considered a metalloid, As possesses properties intermediate between metals and nonmetals, because it can form metal alloys, but also covalent bonds with carbon, hydrogen, and oxygen. It originates naturally in the environment and occupies an important place in the list of the most abundant elements: the 20th place in the earth's crust, 14th in seawater, and 12 th place in the human body; moreover, it is a component of more than 245 minerals. ${ }^{7,8}$
Usually, the organic compounds of metals are more toxic than the inorganic forms, eg, mercury. However, this is not the case for As; for this particular element, the organic forms are significantly less toxic than the inorganic ones. The toxicity of As decreases from inorganic compounds containing As in the trivalent form (arsenic trioxide, sodium arsenite, arsenic trichloride, etc), to inorganic compounds of pentavalent As (arsenic pentoxide, arsenic acid, lead arsenate, calcium arsenate, etc), and finally the organic compounds (oAs), which are the least toxic ones (dimethylarsinate [DMA] and monomethylarsonate [MMA]). ${ }^{9}$

The main routes of As exposure to humans are air, water, food, and soil. In general, when As is introduced into the body through the diet, the level of absorption in the gastrointestinal tract depends on the chemical species, oxidation state, water solubility, and complexity of the food matrix. For instance, about $95 \%$ of arsenite and arsenate from drinking water is rapidly absorbed after ingestion. ${ }^{10}$

Meharg et $\mathrm{al}^{11}$ claim that the bioavailability of As, both oAs and iAs, in the intestine through the consumption of rice is an open question. In the literature, there are in vitro simulations suggesting that only in the intestine, the availability of iAs through cooked rice consumption is in the range between $60 \%$ and $100 \% .{ }^{12-14}$ The only in vivo study was in animals, and it showed $90 \%$ bioavailability in blood monitoring. ${ }^{15}$

Generally, once absorbed, iAs enters the bloodstream and is distributed between plasma and erythrocytes. This iAs binds to the globin chains of the hemoglobin molecule. ${ }^{5}$ From the bloodstream, iAs can reach several target organs, including liver, kidney, spleen, and lung, and later on, it accumulates and can be found in hair, nails, and skin. ${ }^{5,16,17}$

In the human body, As experiences large biotransformation mediated by enzymes, resulting in sequential methylation. The methylation of As occurs mainly in the liver via arsenite methyltransferase enzyme (As3MT), which has been isolated from the cytosol of hepatocytes. ${ }^{18}$ In contrast, fibroblasts and urothelial cells do not express As3MT; thus, As is accumulated in these cells. Toxicity due to As in hepatocytes is confirmed by its accumulation in the nucleus and mitochondria. ${ }^{19}$ Other methylation sites are the kidney, testes, and lungs. The most recent method describing As detoxification in the human body is the one elucidated by Hayakawa (Figure 1). ${ }^{20}$

The major metabolites excreted in human urine are organic As species (oAs), basically DMA and MMA, with a typical ratio of DMA (60\%-80\%), MMA (10\%-20\%), and iAs (10\%-20\%) in individuals who do not eat seafood 


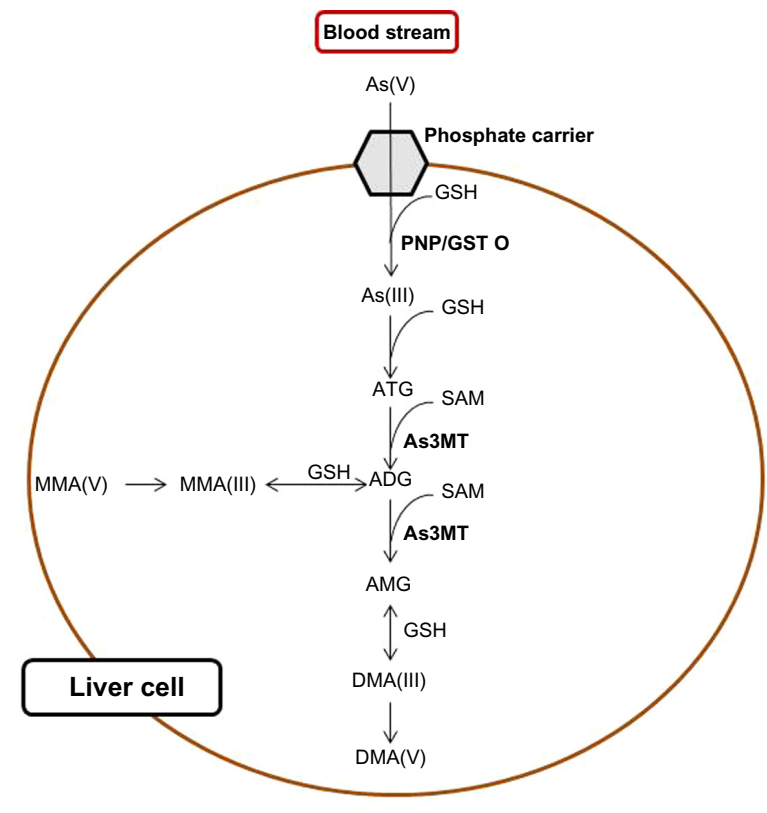

Figure I Arsenic methylation in human hepatocytes, according to Hayakawa's model.

Abbreviations: ATG, arsenic triglutathione; ADG, arsenic diglutathione; AMG, arsenic monoglutathione; $\mathrm{As}(\mathrm{III})$, arsenite; $\mathrm{As}(\mathrm{V})$, arsenate; $\mathrm{MMA}(\mathrm{V})$, monomethylarsonate; MMA(III), monomethylarsonite; DMA(III), dimethylarsinite; DMA(V), dimethylarsinate; PNP, purine nucleoside phosphorylase; GST $O$, glutathione-s-transferase; As3MT, arsenic(III) methyltransferase; GSH, glutathione.

(fish, shellfish, and algae). ${ }^{21}$ Fish consumption increases urinary excretion of arsenobetaine and DMA in a few days after consumption because they are rich in arsenobetaine and arsenosugars. ${ }^{22}$ Different studies have correlated rice consumption and urinary As excretion, indicating that rice consumption leads to an increased excretion of iAs. ${ }^{23-25}$ Cascio et $\mathrm{al}^{23}$ carried out a biomonitoring study on the effect of rice consumption on urinary arsenicals in a general population group of UK Bangladeshis and UK Caucasians, because the Bangladeshi population still represents the largest rice consumer group in the UK, with an average rice consumption 30 times higher than that of White Caucasians. The main results showed that even if total urinary As did not significantly differ between the two groups, the sum of medians of DMA, MMA, and iAs for the Bangladeshi group was found to be over threefold higher than that of the Caucasians. Urinary DMA and iAs were significantly higher among the UK Bangladeshis than among White Caucasians. In contrast, cationic compounds were significantly lower in the Bangladeshis as compared to the same in Caucasians. Significant positive correlations were found between the levels of both iAs and DMA and the daily rice consumption. The higher DMA and iAs levels in the Bangladeshis were considered by the authors to be the consequence of higher rice consumption in this community. Rice in fact accumulates both iAs and oAs, and after ingestion, iAs can be metabolized through MMA to DMA by humans. ${ }^{23}$

Furthermore, the presence of other elements affects the bioavailability of As. Zinc intake increases the concentration of metallothioneins, favoring detoxification of As. A higher As intake, as compared with that of Se, encourages competition between the elements, and As can replace Se in the Se-dependent enzymes, thereby inactivating them and increasing As toxicity. Nutritional status also influences the risk of exposure to As. Several studies indicate that high intakes of vitamin $\mathrm{C}$ and methionine reduce As toxicity, whereas a deficiency of vitamin A intensifies it. ${ }^{26}$

Arsenic poisoning can be classified as acute or chronic. An oral intake of $100-300 \mathrm{mg}\left(1-5 \mathrm{mg} \mathrm{kg}^{-1} \mathrm{bw}\right)$ of iAs in humans usually leads to death within 1 hour, if untreated. ${ }^{10}$ The most relevant and evident signs of As chronic toxicity or arsenicosis are associated with daily consumption of contaminated drinking water. ${ }^{27-29}$ But for those who consume As-free water or water with As content $<10 \mu \mathrm{g} \mathrm{L}^{-1}$, intoxication through rice and rice-based products is considered the main source of poisoning. ${ }^{30}$

The toxicity of iAs has been classified by the International Agency for Research on Cancer in group 1 of carcinogens for humans. ${ }^{29}$ This classification is based on the induction of primary skin, lung, and bladder cancers. For other cancers, such as cancers of the kidney, liver, and prostate, only a very small number of studies have been conducted and the results are certainly not conclusive. Moreover, skin (dermis) lesions, such as hyperpigmentation and palmoplantar hyperkeratosis (blackfoot disease), are sensitive indicators of chronic ingestion of iAs. ${ }^{5}$ These typically appear after 5-10 years of consuming As-contaminated water and may evolve into carcinogenic forms on the skin (nonmelanoma skin cancer) and in the internal organs. ${ }^{30}$

Along with the carcinogenic properties of iAs, a number of noncarcinogenic effects have been proposed. Exposure to As may result in neurobehavioral and neuropathic effects in adolescence, ${ }^{31}$ effects on memory and intellectual function, ${ }^{32}$ reproductive effects with increased fetal loss and premature delivery, ${ }^{27,33}$ steatosis, ${ }^{34}$ cardiovascular diseases,${ }^{35}$ ischemic heart diseases, ${ }^{36}$ carotid atherosclerosis, and respiratory system effects such as chronic cough and chronic bronchitis. ${ }^{37}$ Even at concentrations as low as $0.4 \mu \mathrm{g} \mathrm{L}^{-1}$, iAs has been reported to behave as an endocrine disruptor that is able to alter gene transcription. ${ }^{38}$ Despite the number of in vivo and in vitro studies trying to elucidate the role of As in the development of diabetes in humans, the current available evidences are not adequate to establish a causal role. ${ }^{39,40}$ 
After adjustment for biomarkers of seafood intake, total urine As was found to be associated with increased prevalence of type 2 diabetes by Navas-Acien et al. ${ }^{41}$ These authors reported that their findings support the hypothesis that low levels of chronic exposure to iAs in drinking water, and a widespread exposure worldwide, may play a role in diabetes prevalence. However, more recent studies seem to suggest that there is no such link between As exposure and diabetes. ${ }^{42,43}$

\section{Evidence for presence of As in rice and rice-based products Rice}

First, Sun et $\mathrm{al}^{44}$ proved that the pattern of tAs concentration in rice grain fractions was endosperm $<$ whole grain $<$ bran, with mean values being $560 \mu \mathrm{g} \mathrm{kg}^{-1}, 760 \mu \mathrm{g} \mathrm{kg}^{-1}$, and $3,300 \mu \mathrm{g} \mathrm{kg}^{-1}$, respectively, in rice samples from People's Republic of China and Bangladesh. This pattern of concentration in the different grain parts leads to the fact that brown rice has higher contents of tAs and iAs than polished/ white rice. Commercial bran can reach values as high as $1,000 \mu \mathrm{g} \mathrm{kg}^{-1} \cdot{ }^{44}$

Lombi et $\mathrm{a}^{45}$ reported large differences in the distribution and speciation between the husk, bran, and endosperm of rice (Figure 2). The high content of As in the bran is probably the most important result because nowadays rice bran is widely used as a food additive and as a major health food product. ${ }^{44}$ It should be noted that while pure rice bran is used as a health food supplement, perhaps of greater concern is soluble rice bran, which is marketed as a "superfood" and as a supplement to malnourished children in international aid programs, without adequate toxicological research. Concentrations of As increased significantly from endosperm $\left(540 \mu \mathrm{g} \mathrm{kg}^{-1}\right)$, to bran $\left(6,240 \mu \mathrm{g} \mathrm{kg}^{-1}\right)$, and to husk $\left(12,420 \mu \mathrm{g} \mathrm{kg}^{-1}\right)$.

Among many other authors (Figure 3), ${ }^{44,46-62}$ Meharg et $\mathrm{al}^{52}$ studied the geographical variation in tAs and iAs

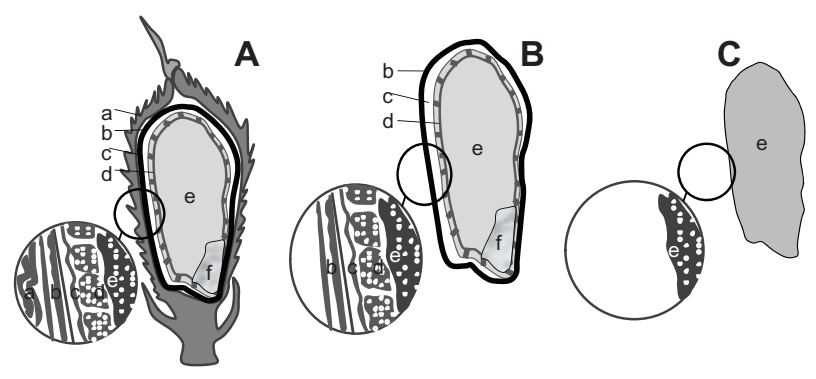

Figure 2 Processing of rice.

Note: Rice processing from paddy (A) to wholegrain or brown (B) and finally to white polished $(\mathbf{C})$ rice.

Abbreviations: a, hull; b, bran; c, polish; d, aleurone layer; e, starchy endosperm; f, embryo. contents of polished rice. An extensive data set of tAs analysis for 901 polished grain samples, originating from ten countries in four continents, was compiled. Egypt $\left(40 \mu \mathrm{g} \mathrm{kg}^{-1}\right)$ and India $\left(70 \mu \mathrm{g} \mathrm{kg}^{-1}\right)$ had the lowest tAs content, while the US $\left(250 \mu \mathrm{g} \mathrm{kg}^{-1}\right)$ and France $\left(280 \mu \mathrm{g} \mathrm{kg}^{-1}\right)$ had the highest content. A subset of 63 samples from Bangladesh, People's Republic of China, India, Italy, and the US was analyzed for As species. The relationship between iAs content versus tAs content significantly differed among countries, with Bangladesh and India having the steepest slope in linear regression, and the US having the shallowest slope. ${ }^{52}$

\section{Infant feed}

Milled rice is a dominant carbohydrate source for weaning babies up to 1 year of age due to its blandness, material properties, low allergenicity, and high nutritional value. As the child develops, the rice porridge is used as the basis of more complex meals, by mixing it initially (from 6 months of age onward) with puréed fruits or vegetables and later (from 8 months onward) with meat (mainly chicken) and fish (mainly hake), either home-made mixtures with baby rice or pre-prepared commercial products. This dependence on rice is exacerbated in infants with food intolerances.

Several studies have proved that high iAs levels are also present in rice products intended for babies and infants. First, Meharg et $\mathrm{l}^{63}$ and, later, Carbonell-Barrachina et $\mathrm{al}^{64}$ studied the contents of iAs in baby foods based on rice and cereals from Spain, the UK, People's Republic of China, and the US. The iAs contents were significantly higher in gluten-free rice than in cereal mixtures with gluten, placing infants with celiac disease at high risk. All rice-based products displayed a high iAs content, with values being $>60 \%$ of the tAs content and the remainder being basically DMA. Pure rice samples for infants from Spain showed lower iAs content $\left(85 \mu \mathrm{g} \mathrm{kg}^{-1}\right)$ compared to samples from other countries such as People's Republic of China (148 $\left.\mu \mathrm{g} \mathrm{kg}^{-1}\right)$, the USA $\left(125 \mu \mathrm{g} \mathrm{kg}^{-1}\right)$, and the UK $\left(162 \mu \mathrm{g} \mathrm{kg}^{-1}\right)$. The products with the highest contents of both tAs and iAs were those manufactured using organic brown rice, which nowadays has a huge demand among consumers wanting natural and/or ecological products. Hernández-Martínez and Navarro-Blasco ${ }^{65}$ obtained similar results in Spain, where organic samples of infant foods had higher levels of As than conventional food samples. Juskelis et $\mathrm{al}^{66}$ determined the contents of the main As species in 30 American infant cereals that were considered to be a potential health risk to the infant population. The results indicated 


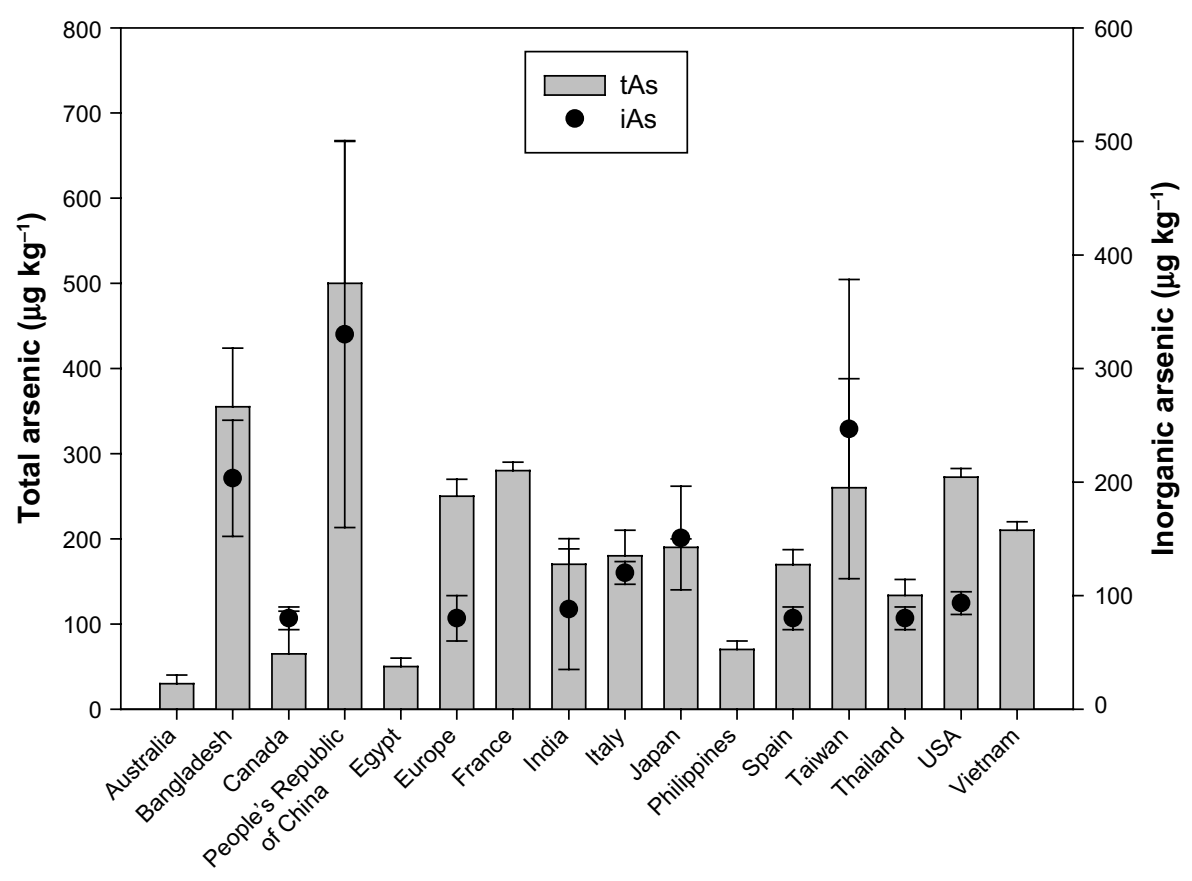

Figure 3 Content of tAs (bars) and iAs (black dots) in rice samples from different countries/regions.

Notes: Data from Australia, ${ }^{46}$ Bangladesh, ${ }^{44,46,48-52}$ Canada, ${ }^{50,53}$ People's Republic of China, ${ }^{44,46,47,52,54}$ Egypt, ${ }^{52}$ Europe, ${ }^{50}$ France, ${ }^{52}$ India, ${ }^{50,52,56,61,62}$ Italy, ${ }^{50,52}$ Japan, ${ }^{52,55}$ Philippines, ${ }^{46}$ Spain, ${ }^{50,52,56}$ Taiwan, $^{57,58}$ Thailand, ${ }^{46,50,52,56}$ USA, ${ }^{50,52,56,59}$ Vietnam. $^{60}$

Abbreviations: tAs, total arsenic; iAs, inorganic arsenic.

high levels of iAs contamination, with values ranging from $55 \mu \mathrm{gg}^{-1}$ to $158 \mu \mathrm{g} \mathrm{kg}^{-1}$.

\section{Celiac disease and lactose intolerance}

Celiac disease is a digestive illness that damages the mucous membrane of the small intestine and interferes with absorption of nutrients from food. This illness is caused by intolerance to gluten proteins. The diet for people suffering from this disease basically consists of eliminating all foods having wheat, rye, and barley. Rice is therefore essential for the manufacture of supplies for celiac disease-affected people and reaches high percentages in their formulations..$^{67,68}$

Munera-Picazo et al ${ }^{69,70}$ conducted two studies evaluating the occurrence of As in foods intended for children and adults who suffer from celiac disease. A positive relationship between rice percentage and As content was clearly observed (Figure 4). Moreover, gluten-free products that do not contain rice in their formulations do not contain As above the detection limit. The highest values of tAs and iAs found were $256 \mu \mathrm{g} \mathrm{kg}^{-1}$ and $128 \mu \mathrm{g} \mathrm{kg}^{-1}$, respectively, and corresponded to samples of pasta for children. In adults, tAs and iAs reached contents as high as $120 \mu \mathrm{g} \mathrm{kg}^{-1}$ (pasta) and $85.8 \mu \mathrm{g} \mathrm{kg}^{-1}$ (baking flour). The daily estimated intake of iAs from the studied rice-based products ranged from $0.61 \mathrm{\mu g} \mathrm{kg}^{-1}$ bw to $0.78 \mu \mathrm{g} \mathrm{kg}^{-1}$ bw for children and $0.47 \mu \mathrm{g} \mathrm{kg}^{-1}$ bw to $0.46 \mu \mathrm{g} \mathrm{kg}^{-1} \mathrm{bw}$ for adults. These levels are within the $\mathrm{BMDL}_{01}$ values identified by the EFSA, and, consequently, a risk to this segment of consumers cannot be excluded.

Lactose intolerance is the inability to digest and metabolize lactose due to the lack of lactase, the enzyme required to break down lactose in the digestive system. ${ }^{71}$ An alternative to breast milk and animal milk is soybean milk or rice milk. An increase in the intake of rice products can imply an increase in the intake of As. Results of two studies on rice milk proved that all samples of the EU and the US fail the maximum residue limit established for water $\left.\left(10 \mu \mathrm{g} \mathrm{L}^{-1}\right)\right)^{70,72}$

\section{Ways to reduce arsenic in rice and rice-based products}

The feasible options to reduce the intake of iAs through rice range from using rice varieties with restricted As uptake and upward transport of As and cultivating rice in geographical areas with low contents of soil As (this would be easily achievable through knowledge of historical contamination of rice-growing areas) to the most drastic and dramatic option of not using rice as a source of carbohydrates and proteins but using other grains, such as oat, corn, or wheat. But this last option would create a huge crisis and it is not feasible at all. 


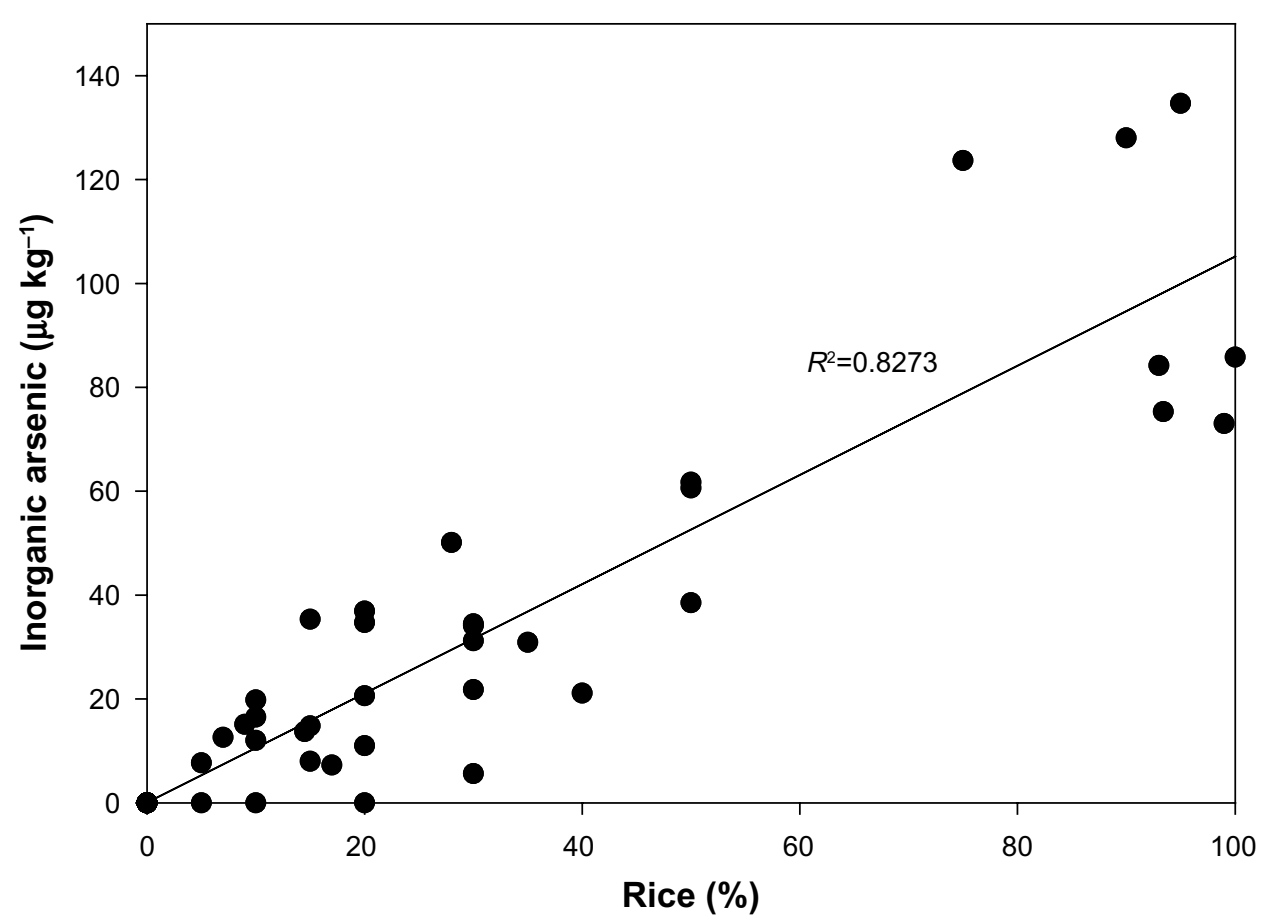

Figure 4 Relationship between iAs and rice percentage in samples of rice-based foods for children and adults with the celiac disease. Abbreviation: iAs, inorganic arsenic.

While an appropriate selection of cultivars is routinely conducted and rice plants with reduced uptake are fully available to farmers, intermediate options have to be used. These include changing farming practices, pretreating rice before entering it into the normal processing chain of the food industry, and optimizing the working conditions of key unit operations to reduce the content of As in rice, if possible.

\section{Agronomic practices}

It has been shown that different growing regions of a country can produce rice with different As contents. For example, in Spain, the As contents in rice for Andalusia (Cadiz and Seville) are generally much lower than those of other areas (Valencia, Tarragona. and Calasparra). ${ }^{56}$ Therefore, the first step in reducing the content of As in rice is to determine the levels of contamination and identify areas that have low levels of As. These comparisons will allow the identification of cultivars that have been used in these geographical areas with reduced As content and also highlight farming practices that could be specific for these areas.

Studies by Norton et $\mathrm{al}^{73}$ have clearly demonstrated that As uptake, transport, and accumulation in edible rice grain are affected by cultivar. Therefore, an appropriate selection of cultivars is the first issue to be studied.

In general, French rice has very high As content. This may be due to the specific cultivars used in the Camargue or may be due to the availability of land and/or management practices. One option to reduce this problem through farming practices could be the addition of organic matter or usage of organic matter-rich soils, leading to intensified As methylation, which may be a desirable process because, as previously mentioned, oAs forms are less toxic than iAs forms.

Finally, we should mention that the aerobic culturing of rice is starting to be considered around the world in order to increase efficiency in the management of nitrogen fertilizers and mainly because water is becoming less and less available worldwide. Compared to continuous flooding of rice fields, aerobic management significantly reduces As availability for plant uptake by conserving As-adsorbent materials such as iron hydro(oxides), and thereby reducing the final As content in edible grain. ${ }^{74}$ However, aerobic conditions may affect the availability of other toxic elements, such as cadmium $(\mathrm{Cd})$. Moreno-Jiménezet al ${ }^{75}$ conducted an experiment over 7 consecutive years, evaluating the impact of water management on accumulation of $\mathrm{As}$ and $\mathrm{Cd}$ in rice. Sprinkler irrigation was compared to traditional flooding irrigation. Successive sprinkler irrigation over 7 years decreased tAs to one-sixth of its initial concentration in the flooded system, while one cycle of sprinkler irrigation also reduced tAs by one-third. iAs concentration increased up to two-folds under flooded conditions compared to sprinkler-irrigated fields, while oAs was also lower in sprinkler system treatments, but to a 
lesser extent. This suggests that methylation is favored under water logging. However, sprinkler irrigation increased $\mathrm{Cd}$ transfer to the grain by a factor of 10 . Sprinkler systems in paddy fields are able to mitigate excessive As accumulation, but this experiment showed that an increased $\mathrm{Cd}$ load in rice grain may result. In summary, it is desirable to reduce iAs content of rice, by altering agronomic practices, but it is essential that these changes do not detrimentally impact the nutritional value of rice, including essential minerals ( $\mathrm{Fe}$ and $\mathrm{Zn}$ ) and vitamins, or increase the content of other toxic elements, such as $\mathrm{Cd}{ }^{76}$

\section{Rice processing}

Rice processing is a combination of several operations to convert paddy into well-milled, silky white rice, which has superior cooking quality attributes. ${ }^{77,78}$

Rice can be classified, according to its different processing steps, into paddy, wholegrain brown rice, and milled white rice. During rice processing, different by-products or coproducts are produced, including hull and bran. Moreover, white rice (the final product) can also reach its final commercial stage in different forms: large broken rice, small broken rice, and rice flour. ${ }^{79}$

Signes et $\mathrm{al}^{78}$ compared the two rice dehusking processes (removal of the external hull or husk of the rice grain) currently in use in India, wet (soaking and boiling of rice and mechanical hulling, leading to parboiled rice) and dry (mechanical hulling, leading to atab rice). The dry method was recommended if As-free water was not available; however, soaking and light boiling resulted in lower As concentrations if nonpolluted water was used. Therefore, the use of high volumes of water for washing and boiling the rice could be good ways of easily and significantly reducing the As content of rice, before starting the production of rice flour for rice-based infant foods. Later, brown or white rice can be cooked before entering the final manufacture of rice-based products. ${ }^{78}$

\section{Recommendations for limiting the final intake of As and for improving consumer confidence on rice and rice-based products}

When consumers have already made the purchase of rice or rice-based products, there are still other options available to reduce the possible presence of As in this food at home. Mainly, these options are based on the safety of the water used for cooking, and the cooking process (temperature and time).
The three most common methods of cooking rice in Asia are known as 1) traditional, 2) intermediate, and 3 ) contemporary. In the traditional method, the rice is washed until the washings become clear, the washings are discarded, and the rice is boiled in excess of water until cooked; finally, the remaining water is discarded. The intermediate method of cooking is similar to the traditional one but rice is boiled using less water, and cooking is finished when no water is left. Finally, in the contemporary method, rice is not washed and it is boiled with a low water volume until there is no water left. ${ }^{77}$ Signes et $\mathrm{al}^{80}$ simulated three cooking methods in their facilities, and the use of the traditional method is recommended (using large volumes of water for the cooking and washing steps); this method significantly reduces the content of tAs to $387-258 \mu \mathrm{g} \mathrm{kg}^{-1}$. Similar conclusions were previously reached by Sengupta et $\mathrm{al},{ }^{77}$ who cooked rice using water with low As content $\left(<3 \mu \mathrm{g} \mathrm{L}^{-1}\right)$ using traditional and modern methods and found that the traditional method (wash until clear; cook with rice: water ratio of 1:6; and discard excess water) removed up to $57 \%$ As from the initial rice. Approximately half of the As was lost in the wash water and the other half in the discard water. ${ }^{77}$

Simultaneously, Signes et al, ${ }^{80}$ cooking simulated rice with different levels of As $\left(>50 \mu \mathrm{g} \mathrm{L}^{-1}\right)$ species in the cooking water, concluded that As concentration in cooked rice was always higher than that of the raw rice and varied in the range of 227-1,642 $\mathrm{g} \mathrm{kg}^{-1}$. Mondal and Polya ${ }^{61}$ reported values of As in cooked rice $\left(170 \mu \mathrm{g} \mathrm{kg}^{-1}\right)$ from two surveys of households in West Bengal, Nadia district, India; Smith et $\mathrm{al}^{81}$ reported As values of $350 \mu \mathrm{g} \mathrm{kg}^{-1}$ in a survey of households in Bangladesh; Bae et al ${ }^{82}$ reported values of $270 \mu \mathrm{g} \mathrm{kg}^{-1}$ for a site survey in Bangladesh; Rahman et al ${ }^{83}$ reported As levels of $320 \mu \mathrm{g} \mathrm{kg}^{-1}$ during a field study in Bangladesh; and Roychowdhury et $\mathrm{al}^{26}$ reported values of $370 \mu \mathrm{g} \mathrm{kg}^{-1}$ from a household survey in West Bengal, India. Finally, Raab et $\mathrm{al}^{84}$ systematically investigated tAs and iAs in different types of basmati, long grain, polished, and whole rice samples that had been subjected to various types of cooking processes using uncontaminated water. The effects of washing-rinsing, low volume of water (rice-to-water ratio 1:2.5), and high volume of water (ratio of water to rice: 1:6) during cooking and steaming were investigated. Rinsing and washing were effective in eliminating about $10 \%$ of tAs and iAs in basmati rice, but these were less effective for other types of rice. While steaming reduced tAs and iAs contents in rice, it did not consistently affect all types of rice investigated. The use of a large water volume for cooking effectively reduced both 
tAs and iAs, 35\% and 45\%, respectively, in the long-grain basmati rice as compared to the reduction in raw rice. This study indicated that washing and rinsing with high volumes of clean water are effective in reducing the As (especially iAs) content of cooked rice.

Furthermore, Signes et $\mathrm{al}^{80}$ demonstrated that As speciation was not significantly affected by the cooking process, probably because the temperature reached during cooking of rice, $100^{\circ} \mathrm{C}$, is lower than that required for promoting exchange of species. Van Elteren and Slejokovek ${ }^{85}$ studied the effect of high temperature on As speciation in aqueous As standard solutions and concluded that temperatures above $150^{\circ} \mathrm{C}$ are required to establish significant changes. A later study by Devesa et $\mathrm{al}^{86}$ agreed with this statement and concluded that these high temperatures can be achieved in some cooking treatments in which the food surface is in direct contact with the source of heat (grilling, frying, or baking); temperatures as high as $250^{\circ} \mathrm{C}$ can be reached. Similar results were found by Hanaoka et $\mathrm{al}^{87}$ and Torres-Escribano et al. ${ }^{88}$

As the final conclusion, proper labeling is essential for this type of product. It is required to express the percentage of rice used, in addition to the variety and its origin. This information will be useful and improve consumer confidence in these products.

In summary, the rice industry has to know the possible options to limit this problem. Here are some objectives to be reached:

- To identify rice varieties accumulating low levels of iAs.

- To use rice cultivars that show restricted As uptake, use aerobic cultivation practices, and avoid upward As transport to the edible grain.

- To facilitate increased production of rice in regions with low contents of As.

- To optimize rice cooking, by using more water to facilitate the migration of As to the rinsing/washing/cooking water.

- To limit the use of whole grain rice (containing bran) for the segment of population with high intake of rice, for instance, people with celiac disease.

\section{Disclosure}

The authors report no conflicts of interest in this work.

\section{References}

1. Food and Agriculture Organization of the United Nations. Rice Market Monitor. 12(1); 2014. Available from: http://www.fao.org/economic/ RMM. Accessed September 1, 2014.
2. Signes-Pastor AJ, Mitra K, Sarkhel S, et al. Arsenic speciation in food and estimation of the dietary intake of inorganic arsenic in a rural village of West Bengal, India. J Agric Food Chem. 2008;56:9469-9474.

3. Zhao FJ, McGrath SP, Meharg AA. Arsenic as a food chain contaminant: mechanisms of plant uptake and metabolism and mitigation strategies. Annu Rev Plant Biol. 2010;61:535-559.

4. Codex Alimentarius Commission. Joint FAO/WHO food standards programme. 37th session. Distribution of the report of the eighth session of the Codex Committee on contaminants in foods, Geneva, Switzerland; 2014. Available from: http://www.fao.org/. Accessed September 1, 2014.

5. European Food Safety Authority. Panel on contaminants in the food chain. Scientific opinion on arsenic in food. EFSA J. 2009;7:1351.

6. Food and Agriculture Organization/World Health Organization (FAO/ OMS). Summary and conclusions of the seventy-second meeting of the joint FAO/WHO expert committee on food additives (JECFA). FAO, Rome, Italy; WHO, Geneva, Switzerland; 2010. Available from: http://www.who.int/foodsafety/chem/summary72_rev.pdf. Accessed September 1, 2014.

7. Selene CH, Chou J, De Rosa CT. Case studies - arsenic. Int J Hyg Environ Health. 2003;206:381-386.

8. Mandal BK, Suzuki KT. Arsenic round the world; a review. Talanta. 2002;58:201-235.

9. Agency for Toxic Substances and Disease Registry. Decision guide for identifying substance-specific data needs related to toxicological profiles; notice. US department of health and human services, public health service, Atlanta, US. Fed Regist. 1989;54:37618-37634.

10. Agency for Toxic Substances and Disease Registry. Toxicological profile for arsenic. US Department of Health and Human Services, Public Health Service, Atlanta, US; 2007. Available from: http://www. atsdr.cdc.gov/toxprofiles/tp2.pdf. Accessed September 1, 2014.

11. Meharg AA, Williams PN, Deacon CM, et al. Urinary excretion of arsenic following rice consumption. Environ Pollut. 2014;194:181-187.

12. Ackerman AH, Creed PA, Parks AN, et al. Comparison of a chemical and enzymatic extraction of arsenic from rice and an assessment of the arsenic absorption from contaminated water by cooked rice. Environ Sci Technol. 2005;39:5241-5246.

13. Laparra JM, Vélez D, Barberá R, Farré R, Montoro R. Bioavailability of inorganic arsenic in cooked rice: practical aspects for human health risk assessments. J Agric Food Chem. 2005;53:8829-8833.

14. Sun GX, Van de Wiele T, Alava P, Tack F, Du Laing G. Arsenic in cooked rice: effect of chemical, enzymatic and microbial processes on bioaccessibility and speciation in the human gastrointestinal tract. Environ Pollut. 2012;162:241-246.

15. Juhasz AL, Smith E, Weber J, et al. In vivo assessment of arsenic bioavailability in rice and its significance for human health risk assessment. Environ Health Perspect. 2006;114:1826-1831.

16. Hughes MF, Kenyon EM, Edwards BC, Mitchell CT, Del Razo LM, Thomas DJ. Accumulation and metabolism of arsenic in mice after repeated oral administration of arsenate. Toxicol Appl Pharmacol. 2003;191:202-210.

17. Vahter M. Metabolism of arsenic. In: Fowler B, editor. Biological and Environmental Effects of Arsenic. Oxford: Elsevier Science; 1983: 171-197.

18. Dopp E, Hartmann LM, von Recklinghausen U, et al. Forced uptake of trivalent and pentavalent methylated and inorganic arsenic and its cyto/genotoxicity in fibroblasts and hepatoma cells. Toxicol Sci. 2005;87:46-56.

19. Dopp E, Von Recklinghausen U, Hartmann LM. Subcellular distribution of inorganic and methylated arsenic compounds in human urothelial cells and human hepatocytes. Drug Metab Dispos. 2008;36:971-979.

20. Hayakawa T, Kobayashi Y, Cui X, Hirano S. A new metabolic pathway of arsenite: arsenic - glutathione complexes are substrates for human arsenic methyltransferase Cyt19. Arch Toxicol. 2005;79:183-191.

21. Buchet JP, Lauwerys R, Roels H. Comparison of the urinary excretion of arsenic metabolites after a single oral dose of sodium arsenite, monomethylarsonate, or dimethylarsinate in man. Int Arch Occup Environ Health. 1981;48:71-79. 
22. Sanchez-Rodas D, Geiszinger A, Gómez-Ariza JL, Francesconi KA. Determination of an arsenosugar in oyster extracts by liquid chromatography-electrospray mass spectrometry and liquid chromatographyultraviolet photo-oxidation-hydride generation atomic fluorescence spectrometry. Analyst. 2002;127:60-65.

23. Cascio C, Raab A, Jenkins RO, Feldmann J, Meharg AA, Haris PI. The impact of a rice based diet on urinary arsenic. J Environ Monit. 2011;13:257-265.

24. Davis MA, Mackenzie TA, Cottingham KL, Gilbert-Diamond D, Punshon T, Karagas MR. Rice consumption and urinary arsenic concentrations in US children. Environ Health Perspect. 2012;120: 1418-1424.

25. Gilbert-Diamond D, Cottingham KL, Gruber JF. Rice consumption contributes to arsenic exposure in US women. Proc Natl Acad Sci USA. 2011;108:20656-20660.

26. Roychowdhury T, Tokunaga H, Ando M. Survey of arsenic and other heavy metals in food composites and drinking water and estimation of dietary intake by the villagers from an arsenic affected area of West Bengal, India. Sci Total Environ. 2003;308:15-35

27. Chakraborti D, Mukherjee SC, Pati S, et al. Arsenic groundwater contamination in Middle Ganga Plain, Bihar, India: a future danger? Environ Health Persp. 2003;111:1194-1201.

28. Kurzius-Spencer M, O'Rourke MK, Hsu CH, Hartz V, Harris RB, Burgess JL. Measured versus modeled dietary arsenic and relation to urinary arsenic excretion and total exposure. J Expo Sci Environ Epidemiol. 2013;23:442-449.

29. International Agency for Cancer Research. Some drinking-water disinfectants and contaminants, including arsenic. IARC Monogr Eval Carcinog Risks Hum. 2004;84:1-477.

30. Yu G, Sun D, Zheng Y. Health effects of exposure to natural arsenic in groundwater and coal in China: an overview of occurrence. Environ Health Persp. 2007;115:636-642.

31. Tsai SY, Chou HY, The HW, Chen CM, Chen CJ. The effects of chronic arsenic exposure from drinking water on the neurobehavioral development in adolescence. Neurotoxicology. 2003;24:747-753.

32. Calderón J, Navarro ME, Jimenez-Capdeville ME, et al. Exposure to arsenic and lead and neuropsychological development in Mexican children. Environ Res. 2001;85:69-76.

33. Milton AH, Smith W, Rahman B, et al. Chronic arsenic exposure and adverse pregnancy outcomes in Bangladesh. Epidemiology. 2005;16:82-86.

34. Chen H, Li SF, Liu J, Diwan BA, Barrett JC, Waalkes MP. Chronic inorganic arsenic exposure induces hepatic global and individual gene hypomethylation: implications for arsenic hepatocarcinogenesis. Carcinogenesis. 2004;25:1779-1786.

35. Lee MY, Bae ON, Chung SM, Kang KT, Lee JY, Chung JH. Enhancement of platelet aggregation and thrombus formation by arsenic in drinking water: a contributing factor to cardiovascular disease. Toxicol Appl Pharm. 2002;179:83-88.

36. Tseng $\mathrm{CH}$, Chong $\mathrm{CK}$, Tseng CP, et al. Long-term arsenic exposure and ischemic heart disease in arseniasis hyperendemic villages in Taiwan. Toxicol Lett. 2003;137:15-21.

37. Milton AH, Rahman M. Respiratory effects and arsenic contaminated well water in Bangladesh. Int J Environ Health Res. 2002;12: 175-179.

38. Bodwell JE, Kingsley LA, Hamilton JW. Arsenic at very low concentrations alters glucocorticoid receptor (GR)-mediated gene activation but not GR-mediated gene repression: complex dose-response effects are closely correlated with levels of activated GR and require a functional GR DNA binding domain. Chem Res Toxicol. 2004;17: 1064-1076.

39. Tseng CH, Tseng CP, Chiou HY, Hsueh YM, Chong CK, Chen CJ. Epidemiologic evidence of diabetogenic effect of arsenic. Toxicol Lett. 2002;133:69-76.

40. Chen CJ, Wang SL, Chiou JM, et al. Arsenic and diabetes and hypertension in human populations: a review. Toxicol Appl Pharm. 2007;222 298-304.
41. Navas-Acien A, Guallar E. Measuring arsenic exposure, metabolism, and biological effects: the role of urine proteomics. Toxicol Sci. 2008;106:1-4.

42. Argos M, Kalra T, Rathouz PJ, et al. Arsenic exposure from drinking water, and all-cause and chronic-disease mortalities in Bangladesh (HEALS): a prospective cohort study. Lancet. 2010;376: 252-258.

43. Chen Y, Ahsan H, Slavkovich V, et al. No association between arsenic exposure from drinking water and diabetes mellitus: a crosssectional study in Bangladesh. Environ Health Perspect. 2010;118: 1299-1305.

44. Sun GX, Williams PN, Carey AM. Inorganic arsenic in rice bran and its products are an order of magnitude higher than in bulk grain. Environ Sci Technol. 2008;42:7542-7546.

45. Lombi E, Scheckel KG, Pallon J, Carey AM, Zhu YG, Meharg AA. Speciation and distribution of arsenic and localization of nutrients in rice grains. New Phytol. 2009;184:193-201.

46. Williams PN, Islam MR, Adomako EE, Raab A, Hossain SA, Zhu YG. Increase in rice grain arsenic for regions of Bangladesh irrigating paddies with elevated arsenic in groundwaters. Environ Sci Technol. 2006;40:4903-4908.

47. Xie ZM, Huang CY. Control of arsenic toxicity in rice plants grown on an arsenicpolluted paddy soil. Commun Soil Sci Plant Anal. 1998;29: 2471-2477.

48. Meharg AA, Rahman M. Arsenic contamination of Bangladesh paddy field soils: implications for rice contribution to arsenic consumption. Environ Sci Technol. 2003;37:229-234.

49. Islam M, Jahiruddin M, Islam S. Assessment of arsenic in the watersoil-plant systems in gangetic floodplains of Bangladesh. Asian J Plant Sci. 2004;3:489-493.

50. Williams PN, Price AH, Raab A, Hossain SA, Feldmann J, Meharg AA. Variation in arsenic speciation and concentration in paddy rice related to dietary exposure. Environ Sci Technol. 2005;39:5531-5540.

51. Ohno K, Yanase T, Matsuo Y, Kimura T, Hamidur Rahman M, Magara Y. Arsenic intake via water and food by a population living in an arsenic-affected area of Bangladesh. Sci Total Environ. 2007;381: 68-76.

52. Meharg AA, Williams PN, Adamako E. Geographical variation in total and inorganic arsenic content of polished (white) rice. Environ Sci Technol. 2009;43:1612-1617.

53. Heitkemper DT, Vela NP, Stewart KR, Westphal CS. Determination of total and speciated arsenic in rice by ion chromatography and inductively coupled plasma mass spectrometry. J Anal Atom Spectr. 2001;16: 299-306.

54. Liu H, Probst A, Liao B. Metal contamination of soils and crops affected by the chenzhou lead/zinc mine spill (Hunan, China). Sci Total Environ. 2005;339:153-166.

55. Naito S, Matsumoto E, Shindoh K, Nishimura T. Effects of polishing, cooking, and storing on total arsenic and arsenic species concentrations in rice cultivated in Japan. Food Chem. 2015;168:294-301.

56. Burló F, Ramírez-Gandolfo A, Signes-Pastor AJ, Haris PI, Carbonell-Barrachina AA. Arsenic contents in Spanish infant rice, pureed infant foods, and rice. J Food Sci. 2012;71:T15-T19.

57. Lin HT, Wong SS, Li GC. Heavy metal content of rice and shellfish in Taiwan. J Food Drug Anal. 2004;12:167-174.

58. Schoof RA, Yost LJ, Crecelius E, Irgolic K, Goessler W, Guo HR. Dietary arsenic intake in Taiwanese districts with elevated arsenic in drinking water. Hum Ecol Risk Ass. 1998;4:117-135.

59. Schoof RA, Yost LJ, Eickhoff J, Crecelius EA, Cragin DW, Meacher DM. A market basket survey of inorganic arsenic in food. Food Chem Toxicol. 1999;37:839-846.

60. Phuong TD, Chuong PV, Khiem DT, Kokot S. Elemental content of Vietnamese rice. Part 1. Sampling, analysis and comparison with previous studies. Analyst. 1999;124:553-560.

61. Mondal D, Polya DA. Rice is a major exposure route for arsenic in Chakdaha block, Nadia district, West Bengal, India: a probabilistic risk assessment. App Geochem. 2008;23:2987-2998. 
62. Pal A, Chowdhury UK, Mondal D, Das B, Nayak B, Ghosh A. Arsenic burden from cooked rice in the populations of arsenic affected and nonaffected areas and Kolkata city in West-Bengal, India. Environ Sci Technol. 2009;43:3349-3355.

63. Meharg AA, Sun G, Williams PN, et al. Inorganic arsenic levels in baby rice are of concern. Environ Pollut. 2008;152:746-749.

64. Carbonell-Barrachina AA, Wu X, Ramírez-Gandolfo A, et al. Inorganic arsenic contents in rice-based infant foods from Spain, UK, China and USA. Environ Pollut. 2012;163:77-83.

65. Hernández-Martínez R, Navarro-Blasco I. Survey of total mercury and arsenic content in infant cereals marketed in Spain and estimated dietary intake. Food Cont. 2013;30:423-432.

66. Juskelis R, Li W, Nelson J, Cappozzo JC. Arsenic speciation in rice cereals for infants. J Agri Food Chem. 2013;61:10670-10676.

67. National Institute of Diabetes and Digestive and Kidney Diseases. Celiac disease; 2014. Available from: http://digestive.niddk.nih.gov/ ddiseases/pubs/celiac/index.aspx. Accessed September 1, 2014.

68. Green PH, Cellier C. Celiac disease. Review. New England J Med. 2007;357:1731-1743.

69. Munera-Picazo S, Ramírez-Gandolfo A, Burló F, CarbonellBarrachina AA. Inorganic and total arsenic contents in rice-based foods for children with celiac disease. J Food Sci. 2014;79:122-128.

70. Munera-Picazo S, Burló F, Carbonell-Barrachina AA. Arsenic speciation in rice-based food for adults with celiac disease. Food Addit Contam Part A Chem Anal Control Expo Risk Assess. 2014;31: 1358-1366.

71. National Institute of Diabetes and Digestive and Kidney Diseases. Lactose intolerance; 2014. Available from: http://digestive.niddk.nih. gov/ddiseases/pubs/lactoseintolerance/. Accessed September 1, 2014.

72. Meharg AA, Deacon C, Campbell RC, et al. Inorganic arsenic levels in rice milk exceed EU and US drinking water standards. $J$ Environ Monitor. 2008;10:428-431.

73. Norton GJ, Islam MR, Deacon CM, et al. Identification of low inorganic and total grain arsenic rice cultivars from Bangladesh. Environ Sci Technol. 2009;43:6070-6075.

74. Arao T, Kawasaki A, Baba K, Mori S, Matsumoto S. Effects of water management on cadmium and arsenic accumulation and dimethylarsinic acid concentrations in Japanese rice. Environ Sci Technol. 2009;43:9361-9367.

75. Moreno-Jiménez E, Meharg AA, Smolders E, et al. Sprinkler irrigation of rice fields reduces grain arsenic but enhances cadmium. Sci Total Environ. 2014;485:468-473.
76. Oikawa A, Matsuda F, Kusano M, Okazaki Y, Saito K. Rice metabolomics. Rice. 2008;1:63-71.

77. Sengupta MK, Hossain MA, Mukherjee A. Arsenic burden of cooked rice: traditional and modern methods. Food Chem Toxicol. 2006;44:1823-1829.

78. Signes A, Mitra K, Burló F, Carbonell-Barrachina AA. Effect of two different rice dehusking procedures on total arsenic concentration in rice. Eur Food Res Technol. 2008;226:561-567.

79. Munera-Picazo S, Ramírez-Gandolfo A, Cascio C, et al. Arsenic in rice-based infant foods. In: Watson RR, Preedy VR, Zibadi S, editors. Wheat and Rice in Disease Prevention and Health. Benefits, Risks and Mechanisms of Whole Grains in Health Promotion. Amsterdam: Elsevier and AP; 2014:377-391.

80. Signes A, Mitra K, Burlo F, Carbonell-Barrachina AA. Contribution of water and cooked rice to an estimation of the dietary intake of inorganic arsenic in a rural village of West Bengal, India. Food Addit Contam. 2008;25:41-50

81. Smith NM, Lee R, Heitkemper DT, Cafferky KD, Haque A, Henderson $\mathrm{AK}$. Inorganic arsenic in cooked rice and vegetables from Bangladeshi households. Sci Total Environ. 2006;370:294-301.

82. Bae M, Watanabe $\mathrm{C}$, Inaoka $\mathrm{T}$, et al. Arsenic in cooked rice in Bangladesh. Lancet. 2002;360:1839-1840.

83. Rahman MA, Hasegawa H, Rahman MM, Miah MAM. Influence of cooking method on arsenic retention in cooked rice related to dietary exposure. Sci Total Environ. 2006;370:51-60.

84. Raab A, Baskaran C, Feldmann J, Meharg AA. Cooking rice in a high water to rice ratio reduces inorganic arsenic content. J Environ Monit. 2009;11:41-44.

85. Van Elteren JT, Slejkovec Z. Ion-exchange separation of eight arsenic compounds by high-performance liquid chromatography - UV decomposition - hydride generation - atomic fluorescence spectrometry and stability test for food treatment procedures. J Chromatogr. 1997;789: 339-340.

86. Devesa V, Velez D, Montoro R. Effect of thermal treatments on arsenic species in food. Food Chem Toxicol. 2008;46:1-8.

87. Hanaoka K, Goessler W, Ohno H, Irgolic KJ, Kaise J. Formation of toxic arsenical in roasted muscles of marine animals. App Organomet Chem. 2001;15:61-66.

88. Torres-Escribano S, Leal M, Vélez D, Montoro R. Total and inorganic arsenic concentrations in rice sold in Spain, effect of cooking, and risk assessments. Environ Sci Technol. 2008;42:3867-3872.
Nutrition and Dietary Supplements

\section{Publish your work in this journal}

Nutrition and Dietary Supplements is an international, peer-reviewed, open access journal focusing on research into nutritional requirements in health and disease, impact on metabolism and the identification and optimal use of dietary strategies and supplements necessary for normal growth and development. The journal welcomes papers covering

\section{Dovepress}

original research, basic science, clinical \& epidemiological studies, reviews and evaluations, guidelines, expert opinion and commentary, case reports and extended reports. The manuscript management system is completely online and includes a very quick and fair peer-review system, which is all easy to use. 